\title{
Article \\ Biological Profiling of Semisynthetic C19-Functionalized
Ferruginol and Sugiol Analogues
}

\author{
Miguel A. González-Cardenete ${ }^{1, *(\mathbb{C})}$, Fatima Rivas ${ }^{2}\left(\mathbb{0}\right.$, Rachel Basset $^{2}$, Marco Stadler $^{3}$, Steffen Hering ${ }^{3}$, \\ José M. Padrón ${ }^{4} \mathbb{D}$, Ramón J. Zaragozá ${ }^{5}$ and María Auxiliadora Dea-Ayuela ${ }^{6, *}$
}

1 Instituto de Tecnología Química (UPV-CSIC), Universitat Politècnica de València-Consejo Superior de Investigaciones Científicas, Avda. de los Naranjos s/n, 46022 Valencia, Spain

2 Department of Chemical Biology and Therapeutics, St. Jude Children's Research Hospital, Memphis, TN 38105, USA; fatima.rivas@stjude.org (F.R.); rachel.bassett@stjude.org (R.B.)

3 Department of Pharmacology and Toxicology, University of Vienna, Althanstrasse 14, A-1090 Vienna, Austria; marco.stadler@univie.ac.at (M.S.); steffen.hering@univie.ac.at (S.H.)

4 BioLab, Instituto Universitario de Bio-Orgánica "Antonio González" (IUBO-AG), Universidad de La Laguna, C/Astrofísico Francisco Sanchez 2, 38200 La Laguna, Spain; jmpadron@ull.es

5 Departamento de Química Orgánica, Universidad de Valencia, Dr. Moliner 50, 46100 Burjassot, Spain; ramon.j.zaragoza@uv.es

6 Departamento de Farmacia, Facultad Ciencias de la Salud, Universidad CEU Cardenal Herrera, C/Ramón y Cajal s/n, 46115 Alfara del Patriarca, Spain

* Correspondence: migoncar@itq.upv.es (M.A.G.-C.); mdea@uchceu.es (M.A.D.-A.)

check for updates

Citation: González-Cardenete, M.A.; Rivas, F.; Basset, R.; Stadler, M.; Hering, S.; Padrón, J.M.; Zaragozá, R.J.; Dea-Ayuela, M.A. Biological Profiling of Semisynthetic C19-Functionalized Ferruginol and Sugiol Analogues. Antibiotics 2021, 10 , 184. https://doi.org/10.3390/ antibiotics 10020184

Academic Editor: Yasunori Yaoita

Received: 25 January 2021

Accepted: 10 February 2021

Published: 12 February 2021

Publisher's Note: MDPI stays neutral with regard to jurisdictional claims in published maps and institutional affiliations.

Copyright: (C) 2021 by the authors. Licensee MDPI, Basel, Switzerland. This article is an open access article distributed under the terms and conditions of the Creative Commons Attribution (CC BY) license (https:/ / creativecommons.org/licenses/by/ $4.0 /)$.

\begin{abstract}
The abietane-type diterpenoids are significant bioactive compounds exhibiting a varied range of pharmacological properties. In this study, the first synthesis and biological investigation of the new abietane-diterpenoid (+)-4-epi-liquiditerpenoid acid (8a) together with several of its analogs are reported. The compounds were generated from the readily available methyl callitrisate (7), which was obtained from callitrisic acid present in Moroccan Sandarac resin. A biological evaluation was conducted to determine the effects of the different functional groups present in these molecules, providing basic structure-activity relationship (SAR) elements. In particular, the ferruginol and sugiol analogs compounds 10-16 were characterized by the presence of a phenol moiety, higher oxidization states at C-7 (ketone), and the hydroxyl, methyl ester or free carboxylic acid at C19. The biological profiling of these compounds was investigated against a panel of six human solid tumor cell lines (HBL-100, A549, HeLa, T-47D, SW1573 and WiDr), four parasitic Leishmania species (L. donovani, L. infantum, L. guyanensis and L. amazonensis) and two malaria strains (3D7 and K1). Furthermore, the capacity of the compounds to modulate gamma-aminobutyric acid type A $\left(\mathrm{GABA}_{\mathrm{A}}\right)$ receptors $\left(\alpha_{1} \beta_{2} \gamma_{2 s}\right)$ is also described. A comparison of the biological results with those previously reported of the corresponding $\mathrm{C} 18$-functionalized analogs was conducted.
\end{abstract}

Keywords: abietane; callitrisic acid; diterpenoid; antiproliferative activity; $\mathrm{GABA}_{\mathrm{A}}$ receptor modulators; antimalarial activity

\section{Introduction}

Chemical diversity in natural products widely attracts scientific attention to find potential therapeutic agents like anticancer drugs from natural sources. Around 79\% of commercial anticancer drugs are either natural products (NPs), directly derived from NPs or inspired in NPs structures [1]. NPs are also sources of novel and selective agents for the treatment of parasitic diseases. Currently, many compounds from plant sources have displayed potential antileishmanial activity; however, none of them have yet undergone clinical trials [2].

Abietane diterpenoids are naturally occurring metabolites isolated from a large variety of terrestrial plants that show a wide range of promising biological activities $[3,4]$. These compounds are characterized by a tricyclic ring system. For example, the phenol 
abietane-type diterpenoid ferruginol (1) (Figure 1) has demonstrated antitumor activity, decreasing non-small cell lung cancer growth after inciting caspase-associated apoptosis. Intraperitoneal administration of ferruginol considerably inhibited the growth of subcutaneous cancer xenograft models [5]. Ferruginol (1) also displays antiproliferative properties in human ovarian cancer and malignant melanoma cells by inhibiting cancer cell migration and inducing apoptosis [6,7], as well as in human thyroid cancer cells [8]. The corresponding C7-oxidized sugiol (2) has shown in vitro cytotoxic activity against human pancreatic and melanoma tumor cell models [9], antitumor activity against EBV-EA activation [10], and in vivo antitumor properties in a prostate DU145 xenograft murine model [11]. Typical semisynthetic bioactive abietane diterpenoids are derived from dehydroabietic acid (3) and dehydroabietylamine (4) (Figure 1), also called leelamine [3].<smiles>CC(C)c1cc2c(cc1O)[C@]1(C)CCCC(C)(C)[C@H]1CC2</smiles><smiles>CC(C)c1cc2c(cc1O)[C@]1(C)CCCC(C)(C)[C@H]1CC2=O</smiles><smiles>[R]C1(C)CCCC2(C)c3ccc(C(C)C)cc3CCC12C</smiles>

$3, \mathrm{R}=\mathrm{CO}_{2} \mathrm{H}$ dehydroabietic acid 4, $\mathrm{R}=\mathrm{CH}_{2} \mathrm{NH}_{2}$ dehydroabietylamine<smiles>CC(C)c1cc2c(cc1S(=O)(=O)[O-])C1(C)CCCC(C)(C(=O)O)C1CC2</smiles>

5, ecabet sodium<smiles>[R20]C(C)(C)C1(C)CCCC2(C)c3ccc(C(C)C)cc3CC[C@H]21</smiles>

6, $R=H$ callitrisic acid 7, $R=$ Me methyl callitrisate<smiles>[R]C1(C)CCC[C@@]2(C)c3cc(O)c(C(C)C)cc3C(=O)C[C@H]12</smiles>

8a, $\mathrm{R}=19-\mathrm{CO}_{2} \mathrm{H}$

(+)-4-epi-liquiditerpenoic acid $\mathrm{A}$ sb, $\mathrm{R}=18-\mathrm{CO}_{2} \mathrm{H}$

$(+)$-liquiditerpenoic acid $\mathrm{A}$<smiles>COC[C@@]1(C)CCC[C@@]2(C)c3cc(OC(C)=O)c(C(C)C)cc3C(=O)C[C@@H]12</smiles><smiles>[R]C1CCCC2(C)c3cc(O)c(C(C)C)cc3CCC12C(=O)OC(=O)O</smiles><smiles>[R]C1CCC[C@]2(C)c3cc(O)c(C(C)C)cc3C(=O)C[C@@H]12</smiles>

15, $\mathrm{R}=\mathrm{CH}_{2} \mathrm{OH}$ 16, $\mathrm{R}=\mathrm{CO}_{2} \mathrm{Me}$

Figure 1. Examples of bioactive abietane diterpenoids $1-7$ and tested molecules $8 a$, and 9-16.

Dehydroabietic acid (3) displays antileishmanial activity in both promastigotes and amastigotes of Leishmania amazonensis [12]. Previously, Moreira and coworkers reported on the antileishmanial activities of dehydroabietic acid derivatives and dehydroabietylamine amides, which were capable of killing Leishmania donovani amastigotes [13,14]. Ferruginol (1) has also shown promising antileishmanial activity against $L$. donovani promastigotes [15]. In addition, dehydroabietic acid (3) from Boswellia thurifera resin has been reported as a positive gamma-aminobutyric acid type $\mathrm{A}\left(\mathrm{GABA}_{\mathrm{A}}\right)$ receptor modulator [16]. Recently, we reported on the synthesis and biological activity of (+)-liquiditerpenoic acid A or abietopinoic acid [17]. In that work, we synthesized and studied biologically (antitumor, $\mathrm{GABA}_{\mathrm{A}}$ modulation and antileishmanial) a series of ferruginol analogs functionalized at C-18 from (-)-abietic acid via methyl dehydroabietate (C-4 epimeric compounds of those depicted in Scheme 1). Despite the important pharmacological properties of abietane diterpenoids, there is only one commercial drug, ecabet, composed of abietane-derived diterpenoids (ecabet sodium (5) (Figure 1) for the treatment of reflux esophagitis and peptic ulcer disease). Thus, this family of natural products offers ample opportunity for further studies due to their promising biological activities. In continuation of our research 
programs on the synthesis and biological analysis of bioactive terpenoid compounds, the synthesis and biological studies of several ferruginol and sugiol analogs functionalized at C-19 is presented herein. The synthesis commenced with methyl callitrisate (7) obtained from the naturally occurring callitrisic acid (6) present in Sandarac resin from Morocco (Figure 1), following our reported protocol [18].

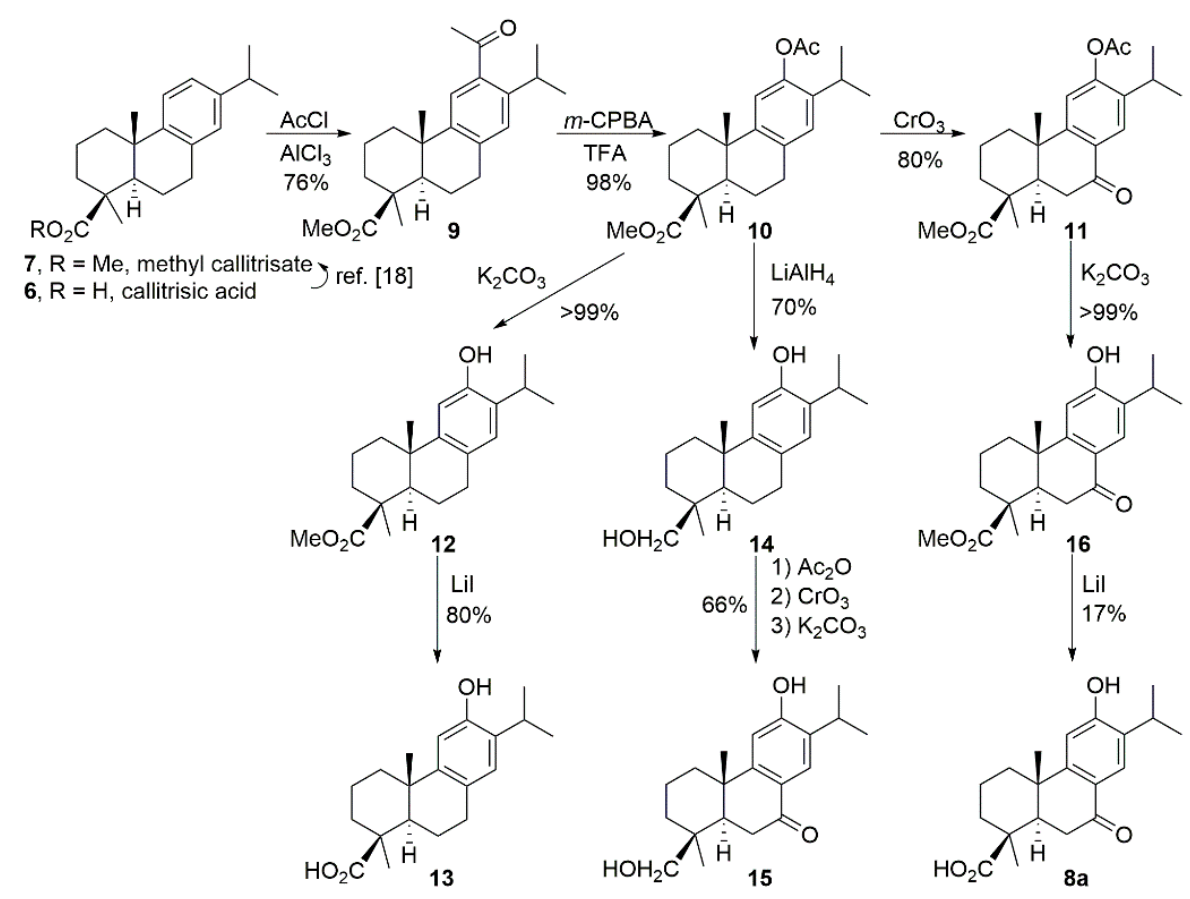

Scheme 1. Synthesis of the tested compounds 8a and 9-16.

In the current study, the semisynthesis of (+)-4-epi-liquiditerpenoic acid A (8a) and analogs (9-16) from methyl callitrisate (7) (Scheme 1) was conducted, their evaluation in a panel of six human solid tumors, four Leishmania species, inhibition of growth of malaria strains 3D7 and K1, and their modulating activity of GABA $A_{A}$ receptor subtype $\alpha_{1} \beta_{2} \gamma_{2 s}$ are reported. Our main objective is to identify new drug leads from the abietanes by better understanding their SAR, and we particularly focused on modifying the functional groups at C-7, C-12 and C-19 to compare with the corresponding C18-functionalized equivalents. It should be noted that very few derivatives of callitrisic acid (6) have been biologically evaluated, making these efforts of great value to the field.

\section{Results and Discussion}

\subsection{Chemistry}

The tested compounds 8a and 9-16 were obtained from (+)-methyl callitrisate (7), which was obtained from callitrisic acid (6) extracted from Sandarac resin [18], as shown in Scheme 1. Compounds 8a, 15 and 16 are novel derivatives. The remaining compounds have either been isolated from natural sources or synthesized by other methods.

Based on previous studies during the synthesis of (-)-sugikurojin A [19], compounds 9 and later 10 were prepared by Friedel-Crafts and Baeyer-Villiger reactions to generate the C-12 phenolic moiety giving the key intermediate 10 (Scheme 1) in 76\% yield for the first step and $98 \%$ yield for the second step. Compound 10 is useful to provide a series of diverse analogs and 4-epi-liquiditerpenoic acid A (8a). First, benzylic oxidation at the C-7 position gave ketone 11, which after methanolysis afforded sugiol analog 16. The nucleophilic cleavage of methyl ester 16 provided the (+)-4-epi-liquiditerpenoic acid A (8a) in $10 \%$ overall yield for the five steps. Additional functional group handling of intermediate 10 led after deacetylation to phenol 12, which was then reacted with LiI to afford lambertic acid (13). Another approach gave directly 19-hydroxyferruginol (14) via 
reduction of 10. Compound 14 was next acetylated, oxidized at C-7, and hydrolyzed to give the new compound 19-hydroxysugiol (15) (Scheme 1). All the obtained compounds presented high purity $(>95 \%)$ by elemental analysis and were synthesized stereoselectively since the stereochemistry at $\mathrm{C}-4$ is fixed in the starting material. Experimental procedures for the synthesis of compounds 8a, 12-16 and their corresponding copies of NMR $\left({ }^{1} \mathrm{H},{ }^{13} \mathrm{C}\right.$ and DEPT) spectra are provided in the Supplementary Materials.

\subsection{Biology}

\subsubsection{Antiparasitic Activity}

Compounds 8a and 9-16 (Scheme 1) were studied for antileishmanial activity in four Leishmania species (L. donovani, L. infantum, L. guyanensis and L. amazonensis), and for cytotoxicity against J774 macrophages, according to established procedures [20]. The results on promastigotes are displayed in Table 1, while those on amastigotes of L. infantum and L. amazonensis are summarized in Table 2. The antimalarial and cytotoxic activities of ferruginol analogs 8a and 9-16 (Scheme 1) were also evaluated against malaria strains 3D7 (chloroquinesensitive) and K1 (chloroquine-resistant), following a previously reported assay [21]. The effects of the compounds on Plasmodium falciparum were calculated as the minimum drug concentration $\left(\mathrm{EC}_{50}\right)$ required to inhibit parasite growth by more than $50 \%$ for $72 \mathrm{~h}$ incubation period with test compounds. The compounds were additionally studied in a panel of mammalian cell lines to determine cytotoxicity. Only those molecules with a relevant selectivity index (SI) are potential lead candidates. The results are displayed in Table 3.

Table 1. Antileishmanial and cytotoxicity $\left(\mathrm{IC}_{50}\right.$ in $\left.\mu \mathrm{M}\right)$ of $\mathrm{C} 19$-functionalized ferruginol and sugiol analogs on in vitro promastigote assay.

\begin{tabular}{|c|c|c|c|c|c|c|c|c|c|}
\hline \multirow{2}{*}{ Compound } & \multicolumn{2}{|c|}{ L. infantum } & \multicolumn{2}{|c|}{ L. donovani } & \multicolumn{2}{|c|}{ L. amazonensis } & \multicolumn{2}{|c|}{ L. guyanensis } & \multirow{2}{*}{$\begin{array}{c}\text { Macrophages J774 } \\
\text { CC }_{50}\end{array}$} \\
\hline & $\mathrm{IC}_{50}{ }^{\mathrm{a}} \pm \mathrm{SD}$ & $\mathrm{SI}^{\mathrm{b}}$ & $\mathrm{IC}_{50} \pm \mathrm{SD}$ & SI & $\mathrm{IC}_{50} \pm \mathrm{SD}$ & SI & $\mathrm{IC}_{50} \pm \mathrm{SD}$ & SI & \\
\hline $1^{d}$ & - & - & 12.2 & $>1.4$ & - & - & - & - & >16.6 (Vero) \\
\hline $8 a$ & $100.3 \pm 20.0$ & $>2.0$ & $84.4 \pm 31.6$ & $>2.4$ & $94.5 \pm 6.5$ & $>2.1$ & $3.0 \pm 0.9$ & $>67.0$ & $>200$ \\
\hline $8 b^{e}$ & $\mathrm{NA}^{\mathrm{f}}$ & & $\mathrm{NA}^{\mathrm{f}}$ & & $\mathrm{NA}^{\mathrm{f}}$ & & $\mathrm{NA}^{\mathrm{f}}$ & & $219.4 \pm 15.0$ \\
\hline 9 & $20.3 \pm 4.6$ & $>10.0$ & $8.9 \pm 2.0$ & $>22.0$ & $14.1 \pm 1.4$ & $>14.0$ & $18.7 \pm 0.8$ & $>10.7$ & $>200$ \\
\hline $9 b^{e}$ & $2.5 \pm 0.6$ & 51.8 & $14.8 \pm 0.9$ & 8.8 & $11.6 \pm 0.6$ & 11.2 & $14.2 \pm 0.4$ & 9.1 & $129.6 \pm 8.9$ \\
\hline 10 & $3.6 \pm 0.6$ & $>8.4$ & $3.9 \pm 0.1$ & $>7.7$ & $7.4 \pm 0.6$ & $>4.1$ & $\mathrm{ND}^{\mathrm{g}}$ & - & $30.2 \pm 2.0$ \\
\hline $10 \mathrm{~b}^{\mathrm{e}}$ & $1.3 \pm 0.1$ & 20.4 & $8.1 \pm 0.7$ & 3.3 & $3.2 \pm 0.3$ & 8.2 & $5.5 \pm 0.7$ & 4.8 & $26.5 \pm 2.7$ \\
\hline 11 & $\mathrm{ND}^{\mathrm{g}}$ & - & ND $g$ & - & $\mathrm{ND}^{\mathrm{g}}$ & - & ND ${ }^{g}$ & - & $45.8 \pm 5.6$ \\
\hline $11 b^{e}$ & $0.7 \pm 0.2$ & 25.4 & $4.4 \pm 0.5$ & 4.1 & $0.65 \pm 0.03$ & 27.4 & $1.3 \pm 0.1$ & 13.6 & $17.8 \pm 2.8$ \\
\hline 12 & ND $g$ & - & $\mathrm{ND}^{\mathrm{g}}$ & - & NDg & - & NDg & - & $65.4 \pm 7.0$ \\
\hline $12 b^{e}$ & $5.0 \pm 0.3$ & 6.8 & $9.21 \pm 0.06$ & 3.7 & $3.9 \pm 0.1$ & 8.7 & $5.9 \pm 1.1$ & 5.8 & $34.2 \pm 3.1$ \\
\hline 13 & $29.1 \pm 1.5$ & 7.5 & $12.8 \pm 2.8$ & 17.0 & $51.5 \pm 3.2$ & 4.2 & $17.8 \pm 1.2$ & 12.2 & $217.4 \pm 34.0$ \\
\hline $13 b^{e}$ & $43.6 \pm 3.4$ & 2.0 & $58.1 \pm 0.7$ & 1.5 & $54.1 \pm 6.5$ & 1.6 & $71.4 \pm 1.5$ & 1.2 & $85.8 \pm 28.8$ \\
\hline 14 & $\mathrm{ND}^{\mathrm{g}}$ & - & $\mathrm{ND}^{\mathrm{g}}$ & - & $\mathrm{ND}^{\mathrm{g}}$ & - & NDg & - & $51.9 \pm 5.9$ \\
\hline $14 b^{e}$ & $0.7 \pm 0.1$ & 33.4 & $13.9 \pm 0.1$ & 1.7 & $7.7 \pm 0.8$ & 3.0 & $12.5 \pm 2.2$ & 1.9 & $23.4 \pm 4.6$ \\
\hline 15 & $\mathrm{ND}^{\mathrm{g}}$ & - & $\mathrm{ND}^{\mathrm{g}}$ & - & $\mathrm{ND}^{\mathrm{g}}$ & - & $\mathrm{ND}^{\mathrm{g}}$ & - & $50.1 \pm 2.4$ \\
\hline $15 b^{e}$ & $9.7 \pm 0.8$ & 1.5 & $19.7 \pm 0.4$ & 0.7 & $10.2 \pm 0.6$ & 1.4 & $16.5 \pm 0.7$ & 0.9 & $14.4 \pm 2.8$ \\
\hline 16 & $10.1 \pm 1.4$ & $>19.8$ & $11.8 \pm 0.8$ & $>16.9$ & $8.5 \pm 0.3$ & $>23.5$ & $5.6 \pm 0.6$ & $>35.7$ & $>200$ \\
\hline $16 b^{e}$ & $\mathrm{ND}^{\mathrm{g}}$ & & ND ${ }^{g}$ & & $\mathrm{ND}^{\mathrm{g}}$ & & NDg & & $153.9 \pm 49.3$ \\
\hline Miltefosine & $3.4 \pm 0.6$ & 40.1 & $0.15 \pm 0.02$ & 909 & $47.7 \pm 5.0$ & 2.9 & $18.2 \pm 0.6$ & 7.5 & $136.4 \pm 1.4$ \\
\hline
\end{tabular}

${ }^{\mathrm{a}} \mathrm{IC}_{50}$, concentration of the compound that gave a $50 \%$ reduction in parasites; SD: standard deviation; ${ }^{\mathrm{b}}$ selectivity index, $\mathrm{SI}=\mathrm{CC}_{50} / \mathrm{IC}_{50}$. ${ }^{c} \mathrm{CC}_{50}(\mu \mathrm{M})$, concentration of the compound that gave a $50 \%$ reduction of cell viability in treated culture cells with respect to untreated ones;

${ }^{d}$ values taken from reference [15]; ${ }^{e}$ refers to C18-congeners. Values taken from reference [17]; ${ }^{\mathrm{f}} \mathrm{NA}$, no activity; ${ }^{\mathrm{g}} \mathrm{ND}$, not determined.

As it is shown in Table 1, compounds 8a, $\mathbf{9}, \mathbf{1 3}$ and $\mathbf{1 6}$ displayed important activity without significant cytotoxicity on J774 macrophage cells $\left(\mathrm{CC}_{50}>200 \mu \mathrm{M}\right)$, being compound $8 \mathrm{a}$ the most potent for L. guyanensis $\left(\mathrm{IC}_{50}=3.0 \mu \mathrm{M}\right.$, SI $\left.>67\right)$. Compound 10, the key intermediate, resulted in being the most active molecule; however, it presented some cytotoxicity on J774 cells. The remaining ferruginol analogs, compounds 11-12 and 14-15, also presented cytotoxicity and were not further studied. It is noteworthy that sugiol analog 16 exhibited better activity against $L$. amazonensis $\left(\mathrm{IC}_{50}=8.5 \mu \mathrm{M}, \mathrm{SI}>23.5\right.$ ) and $L$. guyanensis $\left(\mathrm{IC}_{50}=5.6 \mu \mathrm{M}, \mathrm{SI}>35.7\right)$ parasites compared to the drug miltefosine, used as 
control. It also displayed a better selectivity index $\left(\mathrm{SI}=\mathrm{CC}_{50} / \mathrm{IC}_{50}\right)$ in those Leishmania spp. In the mammalian hosts, Leishmania parasites occur as intracellular amastigotes inside phagolysosomes of macrophages.

Table 2. Antileishmanial and cytotoxicity $\left(\mathrm{IC}_{50}\right.$ in $\left.\mu \mathrm{M}\right)$ of $\mathrm{C} 19$-functionalized ferruginol and sugiol analogs on amastigotes.

\begin{tabular}{|c|c|c|c|c|c|}
\hline \multirow{2}{*}{ Compound } & \multicolumn{2}{|c|}{ L. infantum } & \multicolumn{2}{|c|}{ L. amazonensis } & \multirow{2}{*}{$\frac{\text { Macrophages J774 }}{\mathrm{CC}_{50}{ }^{\mathrm{c}}}$} \\
\hline & $\mathrm{IC}_{50}{ }^{\mathrm{a}} \pm \mathrm{SD}$ & $\mathrm{SI}^{\mathrm{b}}$ & $\mathrm{IC}_{50} \pm \mathrm{SD}$ & SI & \\
\hline $8 a$ & $20.1 \pm 2.0$ & $>9.9$ & $21.4 \pm 2.3$ & $>9.3$ & $>200$ \\
\hline 9 & $22.7 \pm 5.9$ & $>8.8$ & $30.3 \pm 1.2$ & $>6.6$ & $>200$ \\
\hline $9 b^{d}$ & $37.2 \pm 2.4$ & 3.5 & $31.4 \pm 6.2$ & 4.1 & $129.6 \pm 8.9$ \\
\hline 13 & $19.2 \pm 3.8$ & $>11.3$ & $8.8 \pm 1.6$ & $>24.7$ & $217.4 \pm 34.0$ \\
\hline 16 & $16.5 \pm 4.6$ & $>12.1$ & $16.1 \pm 2.0$ & $>12.4$ & $>200$ \\
\hline Miltefosine & $58.1 \pm 4.4$ & 2.3 & $16.5 \pm 1.9$ & 8.2 & $136.4 \pm 1.4$ \\
\hline
\end{tabular}

Compounds 8a, 9, 13 and $\mathbf{1 6}$ are the most active agents in the antipromastigote assay (SI from $>2$ to $>67$ ) and could be good candidates for further research against the clinically relevant Leishmania amastigote forms. Therefore, these ferruginol analogs were tested against L. infantum and L. amazonensis amastigotes (Table 2). When testing on L. infantum amastigotes, the antileishmanial activity of the tested compounds was comparable to that of extracellular forms, except for compound $\mathbf{8 a}$, which demonstrated superior potency. Interestingly, L. amazonensis amastigotes display higher sensitivity to compounds $8 \mathbf{a}$ and 13. Compound $\mathbf{1 3}$ was the most potent against L. amazonensis amastigotes $\left(\mathrm{IC}_{50}=8.8 \mu \mathrm{M}\right)$. Some authors have claimed that a compound should have a selectivity index (SI) value $>20$ to be considered as a potential leishmanicidal agent [22]. This requirement is satisfied by compound 13 (SI > 24.7) against L. amazonensis.

Some structure-activity relationship is deduced in the non-cytotoxic $\left(\mathrm{CC}_{50}>200 \mu \mathrm{M}\right)$ ferruginol analogs. For example, the introduction of a carbonyl group at C-7 in synthetic lambertic acid (13) led to a less active derivative, compound 8a. If the latter is esterified as methyl ester at C19 leads to compound $\mathbf{1 6}$ with an improved pharmacological profile.

On comparing these antileishmanial results with those of the corresponding C18functionalized equivalents (see ref. [17]), some structure-activity relationships could be established. Overall, it can be deduced that the C19-functionalized derivatives are less cytotoxic on J774 cells. It is interesting to note that 4-epi-liquiditerpenoic acid A (8a) displayed activity in the tested promastigote Leishmania spp. strains, particularly, remarkable activity was observed against L. guyanensis while (+)-liquiditerpenoic acid A (8b, Figure 1) was inactive [17].

While no C19-functionalized derivative showed better potency than the reference drug (miltefosine) for L. donovani, it was gratifying to observe improved activity for the C18-congeners. The acetyl derivative 9 was less active, in general than the corresponding C4-epimer in the promastigote stage, but of similar potency in the amastigote forms. Furthermore, after comparing antipromastigote activity of synthetic lambertic acid (13) $\left(\mathrm{IC}_{50}\right.$ values from 12.8 to $51.5 \mu \mathrm{M}$ ) with the corresponding 12-hydroxydehydroabietic acid ( $\mathrm{IC}_{50}$ values from 43.6 to $71.4 \mu \mathrm{M}$, ref. [17]), both superior potency and SI (2.5-fold less cytotoxic) were recorded. It is also important to highlight that the methyl ester of liquiditerpenoic acid $\mathrm{A}$, under the experimental conditions, had solubility problems and was not tested. Herein, we disclose that its corresponding C-19 methyl ester, compound 16 , showed superior activity in both promastigote and amastigote stages over the current standard treatment with miltefosine. The resultant data also indicates that the presence 
of either an acetate group at C12 or a hydroxyl group at C19 leads to more cytotoxic compounds. Briefly, it seems to be essential for antileishmanial activity C19-carboxylic acid or methyl ester along with a C12-hydroxyl group as well as an acetyl group at C12 might lead to active compounds.

The inhibitory values against $P$. falciparum strains ranged from 2.1 to $12.8 \mu \mathrm{M}$, with cytotoxicity properties $>25 \mu \mathrm{M}$ (Table 3 ). Unfortunately, no tested compound improved the values for the parent ferruginol (1) [23]. In general, the presence of either an acetate group at C12 or a hydroxyl group at C19 decreased the biological activity of these compounds $(10,11$ and 14,15$)$.

Table 3. Antiplasmodial activity and cytotoxicity $\left(\mathrm{EC}_{50}-\mu \mathrm{M}\right)$ of ferruginol and sugiol analogs $8 \mathrm{a}, 9-16$ on P. falciparum 3D7 strain, K1 strain, and HepG2, RAJI, BJ, and HEK293 cell lines.

\begin{tabular}{|c|c|c|c|c|c|c|c|c|}
\hline \multirow{3}{*}{ Compound } & \multicolumn{4}{|c|}{ P. falciparum $^{\mathrm{a}}$} & \multicolumn{4}{|c|}{ Cell Lines $b$} \\
\hline & \multicolumn{2}{|c|}{ 3D7 } & \multicolumn{2}{|c|}{ K1 } & \multirow{2}{*}{$\begin{array}{c}\text { HepG2 } \\
\mathrm{EC}_{50}{ }^{\mathrm{c}}\end{array}$} & \multirow{2}{*}{$\frac{\text { RAJI }}{E_{50}{ }^{c}}$} & \multirow{2}{*}{$\frac{\text { BJ }}{E_{50^{c}}}$} & \multirow{2}{*}{$\frac{\text { HEK293 }}{E_{50}^{c}}$} \\
\hline & $\mathrm{EC}_{50}{ }^{\mathrm{c}}$ & SI $^{d}$ & $\mathrm{EC}_{50}{ }^{\mathrm{c}}$ & $S I^{d}$ & & & & \\
\hline $1^{\mathrm{e}}$ & 2.47 & 4.6 & 1.33 & 8.6 & $>25$ & 11.49 & 19.57 & $>25$ \\
\hline $8 a$ & $>15$ & n.c. & $>15$ & n.c. & $>25$ & $>25$ & $>25$ & $>25$ \\
\hline 9 & 12.8 & 1.9 & 12.6 & 2.0 & $>25$ & $>25$ & $>25$ & $>25$ \\
\hline 10 & $>15$ & n.c. & 3.1 & 8.1 & $>25$ & $>25$ & $>25$ & $>25$ \\
\hline 11 & 7.1 & 3.5 & 5.7 & 4.4 & $>25$ & $>25$ & $>25$ & $>25$ \\
\hline 12 & 4.7 & 5.3 & 2.1 & 11.9 & $>25$ & $>25$ & $>25$ & $>25$ \\
\hline 13 & $>15$ & n.c. & $>15$ & n.c. & $>25$ & $>25$ & $>25$ & $>25$ \\
\hline 14 & $>15$ & n.c. & 11.6 & 2.2 & $>25$ & $>25$ & $>25$ & $>25$ \\
\hline 15 & $>15$ & n.c. & 9.4 & 2.6 & $>25$ & $>25$ & $>25$ & $>25$ \\
\hline 16 & 4.8 & 5.2 & 3.9 & 6.4 & $>25$ & $>25$ & $>25$ & $>25$ \\
\hline Chloroquine & 0.023 & n.c. & 0.69 & n.c. & $>25$ & $>25$ & $>25$ & $>25$ \\
\hline Gambogic acid & - & - & - & - & $>25$ & 0.24 & 0.21 & 0.21 \\
\hline Staurosporine & - & - & - & - & $<0.2$ & $<0.2$ & $<0.2$ & $<0.2$ \\
\hline
\end{tabular}

a 3D7 (chloroquine-sensitive) and K1 (chloroquine-resistant); ${ }^{\mathrm{b}} \mathrm{BJ}$, normal human foreskin fibroblast; HEPG2, human liver carcinoma cell line; HEK293, human embryonic kidney cell line; RAJI, Burkitt lymphoma cell line; ${ }^{\mathrm{c}}$ EC50 $(\mu \mathrm{M})$ : concentration corresponding to $50 \%$ growth inhibition of the parasite or cells; ${ }^{\mathrm{d}}$ selectivity index (SI): $\mathrm{EC}_{50}$ lower values of cytotoxic activity $/ \mathrm{EC}_{50}$ values of antimalarial activity. N.C.: not calculated; ${ }^{\mathrm{e}}$ values taken from reference [23].

\subsubsection{Antiproliferative Activity}

The ability of compounds $8 \mathrm{a}$ and 9-16 to inhibit the proliferation of the human solid tumor cell lines HBL-100 (breast), A549 (lung), HeLa (cervix), T-47D (breast), SW1573 (lung), and WiDr (colon) was evaluated in vitro by using the established sulforhodamine B (SRB) [24]. The results are shown in Table $4\left(\mathrm{GI}_{50}\right)$. The anticancer drugs cisplatin and etoposide were used for reference. Most of the molecules were active $\left(\mathrm{GI}_{50}<25 \mu \mathrm{M}\right)$ in the solid tumor cells with higher activity than parent ferruginol (1) and sugiol (2) as reported by Li et al. [25] for A549 cell line and compounds 10-12 better than the starting methyl callitrisate (7) comparing with previous results [26]. The target molecule, (+)-4-epiliquiditerpenoic acid (8a), showed better activity than sugiol (2) for the A549 cell line. The most potent compound, in general for the C19-functionalized series, was compound 14 (19-hydroxyferruginol), characterized by a hydroxyl group at C12 and a hydroxymethyl group at C19. Its activity $(1.8$ to $13.0 \mu \mathrm{M})$ was comparable to etoposide except for the HBL-100 cell line. The moderate cytotoxic activity of 19-hydroxyferruginol (14) for the A549 cell line has been reported to be $\mathrm{IC}_{50}=14 \mu \mathrm{M}$ after measuring by the MTT $(3-(4,5-$ dimethylthiazol-2-yl)-2,5-diphenyl tetrazolium bromide) method [27]. Compounds 10-12 and 14 were more potent than cisplatin and etoposide for the more resistant cell lines WiDr 
and T-47D, demonstrating the potential for further mechanistic studies. Compounds 10-11 were also more potent against the A549 cell line than the drug cisplatin. One clear SAR that can be established is that oxidation at C-7 results in less potent molecules for esters and alcohols (Table 4, compounds 12 and 14 vs. 16 and 15, respectively). On comparing with the corresponding C18-functionalized equivalents [17], in general, the C19-functionalized series is more potent. In particular, the corresponding C18-functionalized analogs of compounds $8 \mathrm{a}, 13,14$ and 16 were less potent for all tested cell lines. Specifically, compound 11 (for HBL-100) and compound 12 (for T-47D and WiDr) and compound 14 (for A549 and HeLa) were the most potent compounds of all C18- and C19-functionalized analogs. Briefly, it seems to be key for important antiproliferative activity in an acetate group at C12 and a C19-hydroxymethyl group. This combination is interesting for designing new molecules.

Table 4. Antiproliferative activity $\left(\mathrm{GI}_{50}\right)$ of 4-epi-liquiditerpenoic acid (8a), and analogs 9-16 against some human solid tumor cells ${ }^{a}$.

\begin{tabular}{|c|c|c|c|c|c|c|}
\hline \multirow{2}{*}{ Compound } & \multicolumn{6}{|c|}{ Cell Line (Origin) } \\
\hline & A549 (Lung) & HBL-100 (Breast) & HeLa (Cervix) & SW1573 (Lung) & T-47D (Breast) & WiDr (Colon) \\
\hline $1^{b}$ & $30.7 \pm 5.2$ & - & - & - & - & - \\
\hline $2^{b}$ & $79.8 \pm 2.2$ & - & - & - & - & - \\
\hline $7^{c}$ & $10.0 \pm 1.9$ & $14.0 \pm 5.0$ & $16.0 \pm 2.5$ & $17.0 \pm 2.2$ & $8.8 \pm 2.7$ & $6.4 \pm 2.1$ \\
\hline $8 a$ & $12.0 \pm 2.9$ & $39.0 \pm 14.0$ & $12.0 \pm 3.8$ & $41.0 \pm 17.0$ & $31.0 \pm 12.0$ & $33.0 \pm 15.0$ \\
\hline $8 b^{d}$ & $>100$ & $>100$ & $85.0 \pm 21.0$ & $>100$ & $>100$ & $>100$ \\
\hline 9 & $15.0 \pm 7.0$ & $14.0 \pm 2.1$ & $15.0 \pm 4.1$ & $25.0 \pm 11.0$ & $14.0 \pm 1.0$ & $15.0 \pm 2.1$ \\
\hline $9 b^{d}$ & $18.0 \pm 2.3$ & $15.0 \pm 1.2$ & $11.0 \pm 1.0$ & $11.0 \pm 4.6$ & $10.0 \pm 1.5$ & $17.0 \pm 2.4$ \\
\hline 10 & $6.5 \pm 2.7$ & $11.0 \pm 2.3$ & $7.0 \pm 1.7$ & $18.0 \pm 3.4$ & $4.2 \pm 1.5$ & $4.5 \pm 1.4$ \\
\hline $10 b^{d}$ & $11.0 \pm 1.8$ & $15.0 \pm 3.9$ & $4.4 \pm 1.1$ & $12.0 \pm 3.2$ & $14.0 \pm 2.9$ & $16.0 \pm 2.5$ \\
\hline 11 & $3.1 \pm 0.9$ & $7.4 \pm 0.7$ & $5.6 \pm 2.9$ & $17.0 \pm 7.5$ & $6.1 \pm 1.9$ & $5.2 \pm 3.1$ \\
\hline $11 b^{d}$ & $14.0 \pm 0.4$ & $16.0 \pm 1.5$ & $13.0 \pm 2.3$ & $17.0 \pm 1.9$ & $20.0 \pm 2.9$ & $19.0 \pm 1.7$ \\
\hline 12 & $2.3 \pm 1.5$ & $11.0 \pm 3.0$ & $5.1 \pm 1.9$ & $12.0 \pm 4.1$ & $4.2 \pm 1.3$ & $3.7 \pm 1.9$ \\
\hline $12 b^{d}$ & $9.4 \pm 2.6$ & $9.7 \pm 2.7$ & $5.8 \pm 0.5$ & $11.0 \pm 2.0$ & $19.0 \pm 3.8$ & $23.0 \pm 4.4$ \\
\hline 13 & $17.0 \pm 6.1$ & $34.0 \pm 4.2$ & $29.0 \pm 13.0$ & $32.0 \pm 8.9$ & $41.0 \pm 8.4$ & $59.0 \pm 7.3$ \\
\hline $13 b^{d}$ & $70.0 \pm 6.3$ & $>100$ & $96.0 \pm 5.5$ & $93.0 \pm 9.3$ & $>100$ & $>100$ \\
\hline 14 & $1.8 \pm 0.4$ & $13.0 \pm 1.6$ & $3.1 \pm 0.9$ & $13.0 \pm 1.3$ & $12.0 \pm 1.8$ & $13.0 \pm 3.7$ \\
\hline $14 b^{d}$ & $12.0 \pm 1.9$ & $16.0 \pm 2.0$ & $12.0 \pm 1.8$ & $15.0 \pm 2.8$ & $16.0 \pm 0.9$ & $17.0 \pm 1.3$ \\
\hline 15 & $10.0 \pm 0.3$ & $17.0 \pm 1.7$ & $15.0 \pm 1.1$ & $19.0 \pm 3.3$ & $19.0 \pm 1.1$ & $17.0 \pm 5.0$ \\
\hline $15 b^{d}$ & $19.0 \pm 3.3$ & $16.0 \pm 2.0$ & $16.0 \pm 2.4$ & $23.0 \pm 0.7$ & $20.0 \pm 2.7$ & $19.0 \pm 2.1$ \\
\hline 16 & $11.0 \pm 6.9$ & $65.0 \pm 4.9$ & $18.0 \pm 1.7$ & $>100.0$ & $47.0 \pm 25.0$ & $6.1 \pm 4.2$ \\
\hline $16 b^{d}$ & $>100$ & $>100$ & $>100$ & $>100$ & $>100$ & $>100$ \\
\hline etoposide & $1.5 \pm 0.3$ & $1.4 \pm 0.1$ & $3.3 \pm 1.6$ & $15.0 \pm 1.5$ & $22.0 \pm 5.5$ & $23.0 \pm 3.1$ \\
\hline cisplatin & $4.9 \pm 0.2$ & $1.9 \pm 0.2$ & $1.8 \pm 0.5$ & $2.7 \pm 0.4$ & $17.0 \pm 3.3$ & $23.0 \pm 4.3$ \\
\hline
\end{tabular}

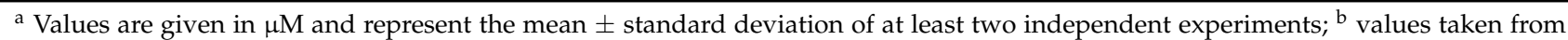
reference [25]; ${ }^{\mathrm{C}}$ values taken from reference [26]; ${ }^{\mathrm{d}}$ refers to C18-congeners. Values taken from reference [17].

\subsection{3. $\mathrm{GABA}_{\mathrm{A}}$ Receptor Modulating Activity}

The compounds $8 \mathrm{a}$ and 9-16 were tested for their properties on the $\mathrm{GABA}_{\mathrm{A}}$ receptor subtype $\left(\alpha_{1} \beta_{2} \gamma_{2 S}\right)$ by means of the two-microelectrode voltage-clamp technique in Xenopus laevis oocytes $[17,26]$. All molecules were tested at concentrations of $10,100 \mu \mathrm{M}$ and compared with dehydroabietic acid (DHA) (3) as a reference [16]. We considered this study interesting since we could obtain some basic SAR on changing the functionalization at C-19 along with the oxygenated moiety at C-12, in comparison to dehydroabietic (3) and callitrisic (6) acids. The results are displayed in Table 5. 19-Hydroxyferruginol (14) showed considerable potentiation $\left(\mathrm{I}_{\mathrm{GABA}}=507 \% \pm 102 \%\right)$ of GABA-evoked currents at $100 \mu \mathrm{M}$ and introduction of a ketone at C-7, compound 15, led to less potent analog $\left(\mathrm{I}_{\mathrm{GABA}}=238 \% \pm 28 \%\right)$. On comparing with the corresponding C18-congeners, the most potent was still 19-hydroxyferruginol (14), and clearly, the change in stereochemistry at $\mathrm{C} 4$ reduced activity. Interestingly, the contrary happened for compounds 12 and 16; both 
methyl esters, which corresponding to $\mathrm{C} 18$-functionalized analogs (12b and $16 \mathrm{~b})$, were more potent compounds. Briefly, it seems to be essential for $\mathrm{GABA}_{\mathrm{A}}$ potentiation of a C19-hydroxymethyl group in these series of compounds along with a C12-hydroxyl group.

Table 5. Potentiation of $\mathrm{I}_{\mathrm{GABA}}$ in $\alpha 1 \beta 2 \gamma 2 \mathrm{~S}$ receptors by compounds $8 \mathrm{a}$, and 9-16.

\begin{tabular}{|c|c|c|}
\hline Compound & $\mathrm{I}_{\mathrm{GABA}}$ Potentiation of $10 \mu \mathrm{M}(\%)$ & $\mathrm{I}_{\mathrm{GABA}}$ Potentiation of $100 \mu \mathrm{M}(\%)$ \\
\hline Dehydroabietic acid (3) & $192 \pm 10$ & $789 \pm 82$ \\
\hline Callitrisic acid (6) ${ }^{a}$ & $14 \pm 5$ & $269 \pm 24$ \\
\hline $8 \mathbf{a}$ & $-8 \pm 1$ & $-8 \pm 3$ \\
\hline $8 b^{b}$ & $-2.2 \pm 4.4$ & $-21.1 \pm 7.1$ \\
\hline 9 & - & - \\
\hline $9 b^{b}$ & $2.7 \pm 0.9$ & $-2.9 \pm 5.1$ \\
\hline 10 & - & - \\
\hline $10 b^{b}$ & $5.1 \pm 2.1$ & $26.3 \pm 8.9$ \\
\hline 11 & $1 \pm 3$ & $75 \pm 4$ \\
\hline $11 b^{b}$ & $-1.0 \pm 2.8$ & $46.7 \pm 8.3$ \\
\hline 12 & $1 \pm 3$ & $65 \pm 6$ \\
\hline $12 b^{b}$ & $23.7 \pm 9.6$ & $378.0 \pm 65.6$ \\
\hline 13 & $3 \pm 3$ & $71 \pm 23$ \\
\hline $13 b^{b}$ & $8.9 \pm 2.3$ & $12.1 \pm 2.9$ \\
\hline 14 & $64 \pm 13$ & $507 \pm 102$ \\
\hline $14 b^{b}$ & $29.3 \pm 10.6$ & $154.1 \pm 34.2$ \\
\hline 15 & $30 \pm 14$ & $238 \pm 28$ \\
\hline $15 b^{b}$ & $4.5 \pm 5.8$ & $-30.3 \pm 9.5$ \\
\hline 16 & $5 \pm 4$ & $104 \pm 26$ \\
\hline $16 b^{b}$ & $37.4 \pm 12.7$ & $242.4 \pm 46.0$ \\
\hline
\end{tabular}

${ }^{\mathrm{a}}$ Values taken from reference [26]; ${ }^{\mathrm{b}}$ refers to C18-congeners. Values taken from reference [17].

\section{Materials and Methods}

\subsection{General Experimental Procedures}

The general details and the extraction of the starting material methyl callitrisate (7) from Moroccan sandarac resin were reported previously [18].

\subsection{Chemistry}

Materials. Key intermediates 10 and 11 were obtained according to conditions reported by us [19]. All compounds prepared in this work display spectroscopic data in agreement with the proposed structures. The purity of all final compounds was $95 \%$ or higher.

\subsection{Biology}

\subsubsection{Antileishmanial Activity}

The parasites, culture procedure and the activity of functionalized abietane analogs on Leishmania promastigotes were performed according to the method previously reported by us [28], while the intracellular amastigote assay was performed on L. amazonensis and L. infantum according to the fluorometric test [29]. The J774 cell culture and the cytotoxicity assay was carried out according to our previously described method [30].

\subsubsection{Antiproliferative Activity}

Cells, cultures and the activity test of abietane analogs followed reported methods [26]. The SRB assay was performed as previously described [24], and the antiproliferative activity was given as $\mathrm{GI}_{50}$ values, which were calculated according to NCI formulas [24].

\subsubsection{Expression of $\mathrm{GABA}_{\mathrm{A}}$ Receptors in Xenopus Laevis Oocytes}

The experiments were carried out according to procedures formerly described [16,26,31].

\subsubsection{Antimalarial Activity}

Assays were performed by using previously described DNA stain-based assay and methods, including cytotoxicity assays [21,23]. 


\section{Conclusions}

To sum up, we have carried out the first chemical synthesis of the abietane (+)-4epi-liquiditerpenoic acid A (8a). It was prepared in a short synthetic sequence of five steps in $10 \%$ overall yield from methyl callitrisate (7). Two parallel routes led to several oxidized analogs, such as naturally occurring lambertic acid (13) or 19-hydroxyferruginol (14). Their accessibility permitted biological profiling of several analogs based on the parent pharmacophore structure of ferruginol (1), that is, 12-hydroxy-8,11,13-abietatriene. This work expands the knowledge on a group of bioactive abietanes and enables us to access additional analogs of these diterpenoids using similar procedures. However, issues of cytotoxicity with respect to antileishmanial activity need to be further studied [32]. Our results demonstrate that these abietane-diterpenoid analogs are sources of promising bioactive molecules with interesting pharmacological properties.

Supplementary Materials: The following are available online at https:/ / www.mdpi.com/2079-6 $382 / 10 / 2 / 184 /$ s1. Experimental procedures for the synthesis of compounds $8 \mathrm{a}, 12-16$ and their corresponding copies of NMR spectra.

Author Contributions: Conceptualization, M.A.G.-C.; formal analysis, M.A.G.-C., F.R., S.H., J.M.P. and M.A.D.-A.; funding acquisition, M.A.G.-C., F.R., S.H., J.M.P. and M.A.D.-A.; investigation, M.A.G.-C., R.B., M.S. and M.A.D.-A.; project administration, M.A.G.-C. and M.A.D.-A.; supervision, M.A.G.-C., F.R., S.H., J.M.P., R.J.Z. and M.A.D.-A.; writing—original draft, M.A.G.-C.; writingreview and editing, M.A.G.-C., F.R., S.H., J.M.P., R.J.Z. and M.A.D.-A. All authors have read and agreed to the published version of the manuscript.

Funding: This research was funded by Spanish National Research Council: 201680I008; Austrian Science Fund: FWF W 1232; American Lebanese Syrian Associated Charities. Santander Bank. Spanish Ministry of Science: PGC2018-094503-B-C22 and "The APC was funded by MDPI".

Institutional Review Board Statement: Not applicable.

Informed Consent Statement: Not applicable.

Data Availability Statement: Not applicable.

Acknowledgments: The Spanish Government (Consejo Superior de Investigaciones Científicas (grant, 201680I008)) is gratefully acknowledged. M.S. thanks the help by the doctoral program "Molecular Drug Targets" (Austrian Science Fund FWF W 1232). F.R. acknowledges the American Lebanese Syrian Associated Charities (ALSAC). M.A.D.-A thanks the Santander Bank for funding of her project in consolidable groups of CEU-UCH. J.M.P. thanks the Spanish Government for financial support, grant PGC2018-094503-B-C22 (MCIU/AEI/FEDER, UE).

Conflicts of Interest: The authors declare no conflict of interest.

\section{References}

1. Newman, D.J.; Cragg, G.M. Natural Products as Sources of New Drugs over the Nearly Four Decades from 01/1981 to 09/2019. J. Nat. Prod. 2020, 83, 770-803. [CrossRef]

2. Singh, N.; Mishra, B.B.; Bajpai, S.; Singh, R.K.; Tiwari, V.K. Natural product based leads to fight leishmaniasis. Bioorg. Med. Chem. 2014, 22, 18-45. [CrossRef]

3. González, M.A. Synthetic derivatives of aromatic abietane diterpenoids and their biological activities. Eur. J. Med. Chem. 2014, 87, 834-842. [CrossRef]

4. González, M.A. Aromatic abietane diterpenoids: Their biological activity and synthesis. Nat. Prod. Rep. 2015, 32, 684-704. [CrossRef] [PubMed]

5. Ho, S.-T.; Tung, Y.-T.; Kuo, Y.-H.; Lin, C.-C.; Wu, J.-H. Ferruginol Inhibits Non-Small Cell Lung Cancer Growth by Inducing Caspase-Associated Apoptosis. Integr. Cancer Ther. 2015, 14, 86-97. [CrossRef]

6. Xiong, W.-D.; Gong, J.; Xing, C. Ferruginol exhibits anticancer effects in OVCAR-3 human ovary cancer cells by inducing apoptosis, inhibition of cancer cell migration and G2/M phase cell cycle arrest. Mol. Med. Rep. 2017, 16, 7013-7017. [CrossRef] [PubMed]

7. Jia, Y.; Wu, C.; Zhang, B.; Zhang, Y.; Li, J. Ferruginol induced apoptosis on SK-Mel-28 human malignant melanoma cells mediated through P-p38 and NF-кB. Hum. Exp. Toxicol. 2019, 38, 227-238. [CrossRef] [PubMed]

8. Luo, G.; Zhou, J.; Li, G.; Hu, N.; Xia, X.; Zhou, H. Ferruginol Diterpenoid Selectively Inhibits Human Thyroid Cancer Growth by Inducing Mitochondrial Dependent Apoptosis, Endogenous Reactive Oxygen Species (ROS) Production, Mitochondrial 
Membrane Potential Loss and Suppression of Mitogen-Activated Protein Kinase (MAPK) and PI3K/AKT Signaling Pathways. Med. Sci. Monit. 2019, 25, 2935-2942. [CrossRef]

9. Fronza, M.; Murillo, R.; Slusarczyk, S.; Adams, M.; Hamburguer, M.; Heinzmann, B.; Laufer, S.; Merfort, I. In vitro cytotoxic activity of abietane diterpenes from Peltodon longipes as well as Salvia miltiorrhiza and Salvia sahendica. Bioorg. Med. Chem. 2011, 19, 4876-4881. [CrossRef]

10. Iwamoto, M.; Minami, T.; Tokuda, H.; Ohtsu, H.; Tanaka, R. Potential Antitumor Promoting Diterpenoids from the Stem Bark of Thuja standishii. Planta Med. 2003, 69, 69-72. [CrossRef]

11. Jung, S.-N.; Shin, D.-S.; Kim, H.-N.; Jeon, Y.J.; Yun, J.; Lee, Y.-J.; Kang, J.S.; Han, D.C.; Kwon, B.-M. Sugiol inhibits STAT3 activity via regulation of transketolase and ROS-mediated ERK activation in DU145 prostate carcinoma cells. Biochem. Pharmacol. 2015, 97, 38-50. [CrossRef]

12. Gonçalves, M.D.; Bortoleti, B.T.S.; Tomiotto-Pellissier, F.; Miranda-Sapla, M.M.; Assolini, J.P.; Carloto, A.C.M.; Carvalho, P.G.C.; Tudisco, E.T.; Urbano, A.; Ambrósio, S.R.; et al. Dehydroabietic acid isolated from Pinus elliottii exerts in vitro antileishmanial action by pro-oxidant effect, inducing ROS production in promastigote and downregulating Nrf2/ferritin expression in amastigote forms of Leishmania amazonensis. Fitoterapia 2018, 128, 224-232. [CrossRef]

13. Vahermo, M.; Krogerus, S.; Nasereddin, A.; Kaiser, M.; Brun, R.; Jaffe, C.L.; Yli-Kauhaluoma, J.; Moreira, V.M. Antiprotozoal activity of dehydroabietic acid derivatives against Leishmania donovani and Trypanosoma cruzi. Med. Chem. Commun. 2016, 7, 457-463. [CrossRef]

14. Pirttimaa, M.; Nasereddin, A.; Kopelyanskiy, D.; Kaiser, M.; Yli-Kauhaluoma, J.; Oksman-Caldentey, K.-M.; Brun, R.; Jaffe, C.L.; Moreira, V.M.; Alakurtti, S. Abietane-type diterpenoid amides with highly potent and selective activity against Leishmania donovani and Trypanosoma cruzi. J. Nat. Prod. 2016, 79, 362-368. [CrossRef] [PubMed]

15. Samoylenko, V.; Dunbar, D.C.; Gafur, M.A.; Khan, S.I.; Ross, S.A.; Mossa, J.S.; El-Feraly, F.S.; Tekwani, B.L.; Bosselaers, J.; Muhammad, I. Antiparasitic, nematicidal and antifouling constituents from Juniperus berries. Phytother. Res. 2008, 22, 1570-1576. [CrossRef] [PubMed]

16. Rueda, D.C.; Raith, M.; De Mieri, M.; Schöffmann, A.; Hering, S.; Hamburger, M. Identification of dehydroabietc acid from Boswellia thurifera resin as a positive GABAA receptor modulator. Fitoterapia 2014, 99, 28-34. [CrossRef]

17. Hamulić, D.; Stadler, M.; Hering, S.; Padrón, J.M.; Bassett, R.; Rivas, F.; Loza-Mejía, M.A.; Dea-Ayuela, M.A.; González-Cardenete, M.A. Synthesis and Biological Studies of (+)-Liquiditerpenoic Acid A (Abietopinoic Acid) and Representative Analogues: SAR Studies. J. Nat. Prod. 2019, 82, 823-831. [CrossRef]

18. González, M.A.; Zaragozá, R.J. Semisynthesis of the antiviral abietane diterpenoid jiadifenoic acid C from callitrisic acid (4-epidehydroabietic acid) isolated from sandarac resin. J. Nat. Prod. 2014, 77, 2114-2117. [CrossRef]

19. González-Cardenete, M.A.; Zaragozá, R.J. A Short and Improved Synthesis of the Antiprotozoal Abietane Diterpenoid (-)Sugikurojin A. Synthesis 2017, 49, 1315-1318. [CrossRef]

20. Dea-Ayuela, M.A.; Bilbao-Ramos, P.; Bolás-Fernández, F.; González-Cardenete, M.A. Synthesis and antileishmanial activity of C7and C12-functionalized dehydroabietylamine derivatives. Eur. J. Med. Chem. 2016, 121, 445-450. [CrossRef]

21. Guiguemde, W.A.; Shelat, A.A.; Bouck, D.; Duffy, S.; Crowther, G.J.; Davis, P.H.; Smithson, D.C.; Connelly, M.; Clark, J.; Zhu, F.; et al. Chemical genetics of Plasmodium falciparum. Nature 2010, 465, 311-315. [CrossRef] [PubMed]

22. Nwaka, S.; Hudson, A. Innovative lead discovery strategies for tropical diseases. Nat. Rev. Drug Discov. 2006, 5, 941-955. [CrossRef]

23. González, M.A.; Clark, J.; Connelly, M.; Rivas, F. Antimalarial activity of abietane ferruginol analogues possessing a phthalimide group. Bioorg. Med. Chem. Lett. 2014, 24, 5234-5237. [CrossRef] [PubMed]

24. Monks, A.; Scudiero, D.; Skehan, P.; Shoemaker, R.; Paull, K.; Vistica, D.; Hose, C.; Langley, J.; Cronise, P.; Vaigro-Wolff, A.; et al. Feasibility of a High-Flux Anticancer Drug Screen Using a Diverse Panel of Cultured Human Tumor Cell Lines. J. Natl. Cancer Inst. 1991, 83, 757-766. [CrossRef]

25. Li, S.; Wang, P.; Deng, G.; Yuan, W.; Su, Z. Cytotoxic compounds from invasive giant salvinia (Salvinia molesta) against human tumor cells. Bioorg. Med. Chem. Lett. 2013, 23, 6682-6687. [CrossRef]

26. Stadler, M.; Padrón, J.M.; González-Cardenete, M.A. Antiproliferative Activity and Effect on GABA $\mathrm{A}_{\mathrm{A}}$ Receptors of Callitrisic Acid Derivatives. Planta Med. Int. Open 2017, 4, e89-e92. [CrossRef]

27. Zhang, L.-C.; Wu, X.-D.; He, J.; Li, Y.; Zhang, R.-P.; Zhao, Q.-S. Three new abietane diterpenoids from Podocarpus fleuryi. Phytochem. Lett. 2013, 6, 364-367. [CrossRef]

28. Bilbao-Ramos, P.; Galiana-Roselló, C.; Dea-Ayuela, M.A.; González-Alvarez, M.; Vega, C.; Rolón, M.; Pérez-Serrano, J.; BolásFernández, F.; González-Rosende, M.E. Nuclease activity and ultrastructural effects of new sulfonamides with anti-leishmanial and trypanocidal activities. Parasitol. Int. 2012, 61, 604-613. [CrossRef] [PubMed]

29. Bilbao-Ramos, P.; Sifontes-Rodríguez, S.; Dea-Ayuela, M.A.; Bolás-Fernández, F. A fluorometric method for evaluation of pharmacological activity against intracellular Leishmania amastigotes. J. Microbiol. Methods 2012, 89, 8-11. [CrossRef]

30. Galiana-Roselló, C.; Bilbao-Ramos, P.; Dea-Ayuela, M.A.; Rolón, M.; Vega, C.; Bolás-Fernández, F.; García-España, E.; Alfonso, J.; Coronel, C.; González-Rosende, M.E. In vitro and in vivo antileishmanial and trypanocidal studies of new $N$-benzene- and $\mathrm{N}$-naphthalenesulfonamide derivatives. J. Med. Chem. 2013, 56, 8984-8998. [CrossRef] 
31. Luger, D.; Poli, G.; Wieder, M.; Stadler, M.; Ke, S.; Ernst, M.; Hohaus, A.; Linder, T.; Seidel, T.; Langer, T.; et al. Identification of the putative binding pocket of valerenic acid on $\mathrm{GABA}_{\mathrm{A}}$ receptors using docking studies and site-directed mutagenesis. Br. J. Pharmacol. 2015, 172, 5403-5413. [CrossRef] [PubMed]

32. Tipparaju, S.K.; Joyasawal, S.; Pieroni, M.; Kaiser, M.; Brun, R.; Kozikowski, A.P. In Pursuit of Natural Product Leads: Synthesis and Biological Evaluation of 2-[3-hydroxy-2-[(3-hydroxypyridine-2-carbonyl)amino]phenyl]benzoxazole-4-carboxylic acid (A33853) and Its Analogues: Discovery of N-(2-Benzoxazol-2-ylphenyl)benzamides as Novel Antileishmanial Chemotypes. J. Med. Chem. 2008, 51, 7344-7347. [CrossRef] [PubMed] 